\title{
Military and monetary power: Are they the right counter-terrorism strategies?
}

\author{
Minh-Hoang Nguyen \\ Ritsumeikan Asia Pacific University \\ Beppu, Oita 874-8577, Japan
}

August 10, 2021

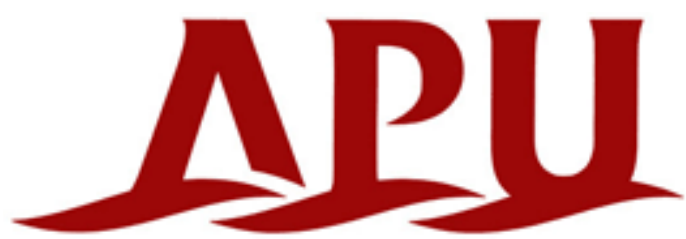

Ritsumeikan Asia Pacific University

$* * * * *$

After warnings of imminent Islamic State attacks into Kabul airport, two suicide bombing attacks finally happened and killed at least 60 Afghan civilians and 13 United States (U.S.) troops on August 26, 2021. The bombing attacks caused the deadliest incident for the U.S. troops since 2011. The ISIS-K, the Islamic State affiliate in Afghanistan, claimed the attacks [1].

The U.S. President Joe Biden immediately condemned and vowed to hunt down people involved in the attack. President Biden said:

"We will not forgive, we will not forget, we will hunt you down and make you pay. Our mission will go on, America will not be intimidated,"

At the same time, he also urged to speed up the withdrawal to meet the August 31 deadline.

During 20 years of Afghanistan occupation, the U.S. has spent $\$ 2.26$ trillion, most of which was used for military purposes [2]. Besides the U.S.'s intelligence services, weapons, training activities, money was also directed to build and train the security forces of the U.S.-backed Afghan government. The forces were even equipped with advanced weapons, including helicopters, armored vehicles and artilleries, etc. It was estimated that the cost of investment in the Afghan forces was around $\$ 83$ billion.

Even with such a tremendous military investment, the U.S.-backed Afghan forces collapsed rapidly only a few days after the U.S. troops fled. The Afghan forces even left behind their millions, or perhaps billions, of dollars worth of military equipment [3]. The 
Taliban captured the equipment, but whether part of it was also captured by other terrorist groups (including the ISIS-K) or not is still unsure.

Two-century efforts of the global war on terror, using overwhelming monetary power and modern destructive weapons, still could not obliterate terrorism. The suicide attacks into Kabul airport are evidence of the existing risks of the return of global terrorism. They, terrorists, might come back stronger and deadlier, using the weapons that used to belong to counter-terrorism fighters to damage their homeland.

So, is it time to rethink the grand global counter-terrorism strategies?

In my opinion, terrorism can be countered by neither modern military weapons, technologies, nor monetary power but through trust-based international collaboration and trust-building activities [4].

\section{References}

1. Aikins M, Hassan S, Gibbons-Neff T, Schmitt E, Pérez-Peña R. (2021). Suicide bombers in Kabul kill dozens, including 13 U.S. troops. The New York Times. Retrieved from https://www.nytimes.com/2021/08/26/world/asia/kabul-airportbombing.html?smid=fb-nytimes\&smtyp=cur

2. Sabga P. (2021). The US spent $\$ 2$ trillion in Afghanistan - and for what? Aljazeera. Retrieved from https://www.aljazeera.com/economy/2021/8/16/theus-spent-2-trillion-in-afghanistan-and-for-what

3. Taylor A. (2021). The Taliban is flaunting captured U.S. weapons that may be worth billions. Can it use them? The Washington Post. Retrieved from https://www.washingtonpost.com/world/2021/08/20/us-weapons-talibanafghanistan/

4. Vuong $\mathrm{QH}$, Nguyen $\mathrm{MH}$, Le TT. (2021). A Mindsponge-Based Investigation into the Psycho-Religious Mechanism Behind Suicide Attacks. Warsaw, Poland: De Gruyter. 